Anomalies of tissue research

SIR - Barbara J. Culliton ("Needed: fetal tissue research" Nature 355, 295; 1992) cites an interesting twist to current US policy banning the use of federal funds for research on fetal tissue transplantation. The twist is that there is no ban on the use of federal funds for fetal tissue research in vitro or in animals. But there is an even more fascinating contradiction. I and many others have received federal funds for the past 30 years to conduct research on the use of normal human fetal fibroblasts to produce human virus vaccines $(A m$. J. Hygiene 75, 240; 1962). WI-38, and other normal human fetal cell strains have been, and still are, used in the United States to produce virus vaccines against poliomyelitis, rubella and rabies.

It is undoubtedly true that many of the same people who promulgated and support the ban have also been the benefactors of human fetal tissue research. Although they are not direct recipients of fetal tissue transplants, tens of millions of people in the United States had, or still have, the viral products of these cells coursing through their veins. When the congressional bill to lift the ban reaches the desk of George Bush, as it soon should, he and his administration might well be reminded of this fact when he vetoes the bill, as he promises to do.

University of California, LEONARD HAYFLICK

San Francisco Medical

School and VAMC,

San Francisco,

California 94121, USA

\section{Rethinking Burt}

SIR - There are two quite different issues involved in the controversy over the late Sir Cyril Burt (Nature 356, 5; 1992). The first is whether Burt was a "senile liar", a "wicked old fraud" and "the biggest scientific scandal since the Piltdown hoax", as he has been variously described in print, and whether he deserves to be pilloried as among the worst of the offenders, for example in Betrayers of the Truth (N. J. Broad \& N. Wade, 1982), and False Prophets (A. Kohn, 1986), for having deliberately fabricated and falsified data to support his conclusions.

In 1980, the British Psychological Society (BPS) officially supported these allegations of academic fraud, about which doubts have now been raised, and the question is whether they were wrong to have done so. There is clearly a prima facie case for looking at the evidence again, and as the BPS is evidently un- willing to do this itself, some other body should undertake the task. That would most appropriately be done by the British Academy, of which Burt had for many years been a distinguished fellow.

The second question is whether Burt's conclusions were in fact correct, assuming that they were not fraudulent. These were that human intelligence is to a large extent genetically heritable, and not much affected by education or other environmental factors.

Burt's data were almost all collected in the 1920s and 1930s, and as he was a pioneer in this field, it is to be expected that some of his methods may have been deficient by modern standards. So, even if most of the original records had not been destroyed after his death in 1971, Burt's conclusions on the inheritance of intelligence and educability could not now be safely accepted without further research, using the best modern methods. This has of course been done, with results that arguably support Burt's position, though that is controversial. It is anyway something that needs to be investigated further, by educational psychologists and others. The BPS itself, however, might now be better advised to avoid taking any corporate stand on the question.

\section{Gonville \& Caius College,} Cambridge CB2 $\mathrm{NA}$, UK

\section{Political pressure?}

SIR - The fact that the reports of the committee of inquiry and of the field expeditions committee were not made available before V. J. Gupta was reinstated at the Panjab University of Chandigarh (see Nature 355, 660; 1992) underlines the possibility that these committees came under political or other pressure - a not uncommon occurrence in India.

\section{National Institute of Nutrition.}

Jamai Osmania PO,

Hyderabad 500007 ,

India

\section{More than survivors}

SIR - Henry Gee's recent insinuation ${ }^{1}$ that the authors of a very interesting reanalysis of the Vigilant et $\mathrm{al}^{2}$ data on mitochondrial Eve are "survivors of the Berkeley group (now all at PSU)" is not only in error but extremely distasteful. Those of us who were fortunate enough to work with Allan Wilson are more numerous than the few of us at Penn State (Maxson, Stoneking and Vigilant) and I can guarantee that none of us see ourselves as "survivors". On the con- trary we are proud students and associates of a highly innovative scientist.

The Hedges et al. paper ${ }^{3}$ is not a rebuttal to Templeton ${ }^{4}$. Templeton showed that the original analysis was 'inadequate' and presented a more parsimonious tree that did not indicate an African root for the data. Hedges et al. examined more than 50,000 trees and then presented the single most likely tree generated by a neighbour-joining algorithm that was more appropriate for the dataset in question.

\section{Institute of Molecular}

LINDA R. MAXSON

Evolutionary Genetics,

Department of Biology,

Penn State University,

University Park,

Pennsylvania 16802, USA

1. Gee, H. Nature 355, 583 (1992).

2. Vigilant, L., Stoneking, M., Harpending, H., Hawkes, K \& Wilson, A. C. Science 253, 1503 (1991).

3. Hedges, S.B., Kumar, S., Tamura, K., \& Stoneking, M. Science 255, 737 (1992)

4. Templeton, A. R. Science 255, 737 (1992)

\section{Uninnovative Japan}

SIR - I agree with Alexander Kennaway (Nature 355, 198; 1992) that being made to conform to bureaucratic budgets and targets handicaps good scientists, but he spoiled his argument by his references to Japan.

For a basic failing of the Japanese 'system' - one largely acknowledged by the Japanese themselves - is that it has not produced a fair share of the world's innovations.

Instead, the Japanese success may be due to the use of innovations by others and perhaps - as proposed by Michael E. Porter in The Competitive Advantage of Nations (Macmillan, London, 1990) - to fierce internal competition between manufacturers, initially behind a high tariff wall. Hardened by that struggle and the consequent need to pay close attention to the consumer, so the theory goes, Japanese manufacturers found the rest of the world easy.

Should this actually be the case theories of industrial development are popular at the moment - then antimerger and antimonopoly laws would be far more important than increasing spending on research.

Research and development do have a place, of course, but it is believed that there is only a slight connection between the breakthroughs of pure science and local industry. Modern information flows are such that industry anywhere can pick up the breakthrough and pay rent for its use.

Australian Financial Review,

MARK LAWSON

273 Jones Street

Ultimo, Sydney,

Australia 2007

NATURE $\cdot$ VOL $356 \cdot 23$ APRIL 1992 